\title{
Stem breakage and forking in low and high elevation Pinus tecunumanii
}

\author{
By B. I. NYokA ${ }^{1)}$, P. TongoonA ${ }^{2)}$ and C. M. GumBIE ${ }^{3)}$
}

(Received $4^{\text {th }}$ June 2009)

\begin{abstract}
Summary
The incidences of stem breakage and forking at ages five and eight years in low and high elevation Pinus tecunumanii were assessed in multilocation provenanceprogeny tests comprising 16 provenances of both low and high elevation $P$. tecunumanii. Stem breakage and forking were found to be more severe at the highest test site (1760m a.s.l.), and progressively declined with decreasing altitude. The mean stem breakage at individual sites for the two ages ranged from $0.7 \%$ to $19.5 \%$ in the low elevation $P$. tecunumanii, while that of the high elevation $P$. tecunumanii was between $0 \%$ and $12.9 \%$. The mean percent of forked trees ranged between $3.9 \%$ and $46.8 \%$ in the low elevation $P$. tecunumanii and from $5.3 \%$ to $27.5 \%$ in the high elevation $P$. tecunumanii. The wide provenance variation in stem breakage and forking suggests that genetic factors related to seed source influence these traits. The low elevation $P$. tecunumanii had significantly higher incidences of stem breakage and forked trees compared to the high elevation $P$. tecunumanii. Overall, provenances with very low levels of stem breakage and forking included San Jerónimo, Montana Sumpul, Las Piedrecitas and Jocón. Although tested on a limited number of sites, the genotype*environment interaction at both provenance and family level appeared to be inconsequential. The mean percent of trees with stem breakage and forks increased between the two assessment ages, with changes ranging from small to more than double, implying that decision on selection against stem breakage and forking should be avoided at five years or earlier. The results of this study showed that the challenges of stem breakage and forking in plantations can be managed by one or a combination of site and seed source selection, while intensive breeding and selection could also be used as a long term strategy.
\end{abstract}

Key words: Stem breakage, forking, low and high elevation Pinus tecunumanii, genotype*environment interaction.

\section{Introduction}

The potential of Pinus tecunumanii (Schwerdtfeger) Eguiluz and J. P. Perry Jr. as a plantation species in Zimbabwe has already been demonstrated in provenance trials (CROCKFORD et al., 1990; NYOKA and BARNES,

\footnotetext{
1) Formerly Principal Tree Breeder, Forestry Commission, Forest Research Centre, Harare. Current address: World Agroforestry Centre, ICRAF-Southern Africa Regional Programme, Chitedze Research Station, P. O. Box 30798, Lilongwe, Malawi. Phone: +265-1-707-329. E-mail: b.nyoka@cgiar.org

2) Professor of Plant Breeding, University of KwaZulu-Natal, African Centre for the Crop Improvement, P. Bag X01, Scottsville, Pietermaritzburg 3209, South Africa. E-mail: tongoona@ukzn.ac.za

3) Biometrician and Deputy General Manager, Forest Research Centre, Forestry Commission, P. O. Box HG595, Highlands, Harare, Zimbabwe. E-mail: cgum@frchigh.co.zw
}

1995; NYOKA et al., 2010). Elsewhere, the species has also demonstrated high growth rates that are comparable and sometimes superior to established species (BIRKS and BARNES, 1995; Hodge and DvoraK, 1999; Moura and DvoraK, 1998; DvoraK et al., 1989; DvORAK et al., 2000a).

Despite its good growth potential, $P$. tecunumanii has shown some unacceptably high levels of stem defects such as stem breakage and forking that may prejudice it against the other established plantation species. Stem breakage occurs when the leader tip of the tree snaps off. This may occur even in moderate winds or as a result of gravity (DvORAK et al., 1993). The primary region of stem breakage is the upper portion of the crown, usually at heavily branched whorls or on region of foxtails. Branching tends to be courser on fertile sites, and this characteristic has been blamed for a significant proportion of broken stems. Foxtails are characterised by uninterrupted apical elongation and formation of the needle fascicles without production of branches or branch primordia. The foxtail may be up to eight metres in length and often ends in formation of branches, which in some cases may be dense and heavy. Where these dense or heavy branches form, often becomes a weak point where breakage occurs.

Forks develop when one or more side branches compete with the leader shoot, often to the extent where the leader shoot loses its dominance or even dies resulting in two or more leader tips. Although there is evidence of genetic control of natural forks, the loss of the terminal shoot could also be caused by severe weather conditions, mechanical damage from bird perching, animal browsing, pest and disease attack. The probability of developing forks is greatest among trees with a prolonged growth period (EKLUNDH-EHRENBERG, 1963; STÅHL, 1990).

Provenance and family variation in stem breakage and forking in $P$. tecunumanii has been reported in Colombia, Brazil, South Africa and Venezuela where average site incidences varied from as low as $0 \%$ to over 60\% (DvoraK et al., 1993; PARFitT, 1996; Moura and Dvorak, 1998; Hodge and Dvorak, 1999). PARFITT (1996) found a significant relationship between stem breakage and branch diameter as well as branch angle. The leader tip of trees with large branches tended to snap off compared to trees with many thin branches. An undesirable relationship was also reported in which the preferred flat or horizontal branch habit was often associated with stem breakage (PARFITT, 1996). Levels of forking were found to follow the same pattern as stem breakage (HODGE and DVORAK, 1999).

Provenance and family variation in the frequency of forking has also been reported in other pines, $P$. chia- 
pensis, (DvoraK et al. (1996); P. oocarpa (Moura et al. 1998); P. kesiya (CosTA and LARS, 2008) and in P. caribaea (MourA and DvorAK, 2001). In the provenance tests that were on many sites, the location effect was found to be highly significant (MOURA and DvorAK, 2001; CosTA and LARS, 2008).

This paper reports on the incidence of stem breakage and forking in both the high and low elevation $P$. tecunumanii at four contrasting sites in Zimbabwe.

\section{Materials and Methods}

Open pollinated seeds were collected from 160 mother trees, representing 16 provenances of $P$. tecunumanii in its natural range by the Oxford Forestry Institute, University of Oxford, UK. The mother trees were selected on the basis of phenotypic superiority in branch quality, stem form, tree size and taper. The selected mother trees in the wild were separated by a minimum distance of $100 \mathrm{~m}$ to avoid possibility of excessive neighbourhood inbreeding. Eight provenances were from the high elevation $P$. tecunumanii (above $1500 \mathrm{~m}$ a.s.l.) and the other eight were from the low elevation $P$. tecunumanii (below $1500 \mathrm{~m}$ a.s.l.). Each of the 16 provenances was represented in the test with 10 mother trees. There were thus 80 families each for the low and high elevation $P$. tecunumanii. Table 1 summarises the geographic location and climatic data of the provenances.

The seed was sown at the John Meikle Forest Research Station, Penhalonga (altitude 1246 m a.s.l.; rainfall $1778 \mathrm{~mm}$; mean temperature $18^{\circ} \mathrm{C}$ ). Sufficient seedlings were raised to establish balanced trials at four sites in the pine plantation growing areas of the eastern highlands of Zimbabwe (Table 2).

Although all the 16 provenances were originally believed to be of $P$. tecunumanii at seed collection and trial establishment, later evidence from molecular makers and morphological traits indicated that one of the provenances, Juquila may not be pure P. tecunumanii (DvoraK et al., 2000b; DvoraK et al., 2007). In this paper, Juquila is taken as a provenance of $P$. tecunumanii, to demonstrate its relevance.

\section{Field design}

The field design was a randomised complete block with five replications and a split plot arrangement of the provenances and families. Provenances were randomised in main plots and the 10 families of each provenance were in turn randomised in subplots. The family was represented by a five-tree line plot with a spacing of $3 \times 3 \mathrm{~m}$. Each provenance plot was therefore a $10 \times 5$ tree rectangular block.

\section{Data analysis}

The tests were assessed at five and eight years for presence and absence of stem breakage or broken tops (brt5 and brt8) and forking (fork5 and fork8). The data of presence and absence of stem breakage and forks was converted to percentages of family subplots based on common denominators. According to STEEL et al. (1997)

Table 1. - Geographic details of the provenances of $P$. tecunumanii used in the study.

\begin{tabular}{|l|l|l|l|l|l|c|c|c|}
\hline Provenance & Code & $\begin{array}{c}\text { Elevation } \\
\text { group }\end{array}$ & Country & $\begin{array}{c}\text { Altitude } \\
\text { range }(\mathbf{m})\end{array}$ & $\begin{array}{c}\text { Latitude } \\
\left({ }^{\circ} \mathbf{N}\right)\end{array}$ & $\begin{array}{c}\text { Longitude } \\
\left({ }^{\circ} \mathbf{W}\right)\end{array}$ & $\begin{array}{c}\text { Rainfall } \\
(\mathbf{m m})\end{array}$ & $\begin{array}{c}\text { Temperature } \\
\left({ }^{\circ} \mathbf{C}\right)\end{array}$ \\
\hline Yucul & Yuc & LE & Nicaragua & $850-1000$ & $12^{\circ} 55^{\prime}$ & $85^{\circ} 48^{\prime}$ & 1394 & 22.4 \\
\hline Culmí & Cul & LE & Honduras & $550-650$ & $15^{\circ} 06^{\prime}$ & $85^{\circ} 21^{\prime}$ & 1325 & 24.3 \\
\hline Villa Santa & Vil & LE & Honduras & $850-950$ & $14^{\circ} 11^{\prime}$ & $86^{\circ} 20^{\prime}$ & 1348 & 22.4 \\
\hline Mt. Pine Ridge & Mpr & LE & Belize & $700-720$ & $17^{\circ} 00^{\prime}$ & $88^{\circ} 55^{\prime}$ & 1558 & 23.9 \\
\hline San Esteban & Est & LE & Honduras & $700-800$ & $15^{\circ} 22^{\prime}$ & $85^{\circ} 35^{\prime}$ & 1400 & 25.0 \\
\hline Jocón & Joc & LE & Honduras & $850-1100$ & $15^{\circ} 16^{\prime}$ & $86^{\circ} 55^{\prime}$ & 1400 & 21.7 \\
\hline San Francisco & Fra & LE & Honduras & $870-1100$ & $15^{\circ} 05^{\prime}$ & $86^{\circ} 20^{\prime}$ & 1600 & 20.0 \\
\hline Finca las Victorias & Vic & LE & Guatemala & $1200-1300$ & $15^{\circ} 12^{\prime}$ & $89^{\circ} 22^{\prime}$ & 1700 & 22.4 \\
\hline Cusuco & Cus & HE & Honduras & $1500-1650$ & $15^{\circ} 30^{\prime}$ & $88^{\circ} 10^{\prime}$ & 2500 & 17.0 \\
\hline La Paz & Paz & HE & Honduras & $1750-2000$ & $14^{\circ} 19^{\prime}$ & $87^{\circ} 45^{\prime}$ & 1619 & 20.0 \\
\hline Guajiquiro & Gua & HE & Honduras & $1835-2250$ & $14^{\circ} 11^{\prime}$ & $87^{\circ} 50^{\prime}$ & 2000 & 15.0 \\
\hline San Jerónimo & Jer & HE & Guatemala & $1700-2000$ & $15^{\circ} 03^{\prime}$ & $90^{\circ} 18^{\prime}$ & 1600 & 17.0 \\
\hline Montana Sumpul & Sum & HE & Honduras & $1950-2050$ & $14^{\circ} 24^{\prime}$ & $89^{\circ} 08^{\prime}$ & 2200 & 16.0 \\
\hline *Juquila & Juq & HE & Mexico & $2000-2250$ & $16^{\circ} 15^{\prime}$ & $97^{\circ} 17^{\prime}$ & 1400 & 14.0 \\
\hline La Soledad & Sol & HE & Guatemala & $2000-2300$ & $14^{\circ} 35^{\prime}$ & $90^{\circ} 25^{\prime}$ & 1543 & 15.0 \\
\hline Las Piedrecitas & Pie & HE & Mexico & $2300-2600$ & $16^{\circ} 46^{\prime}$ & $92^{\circ} 35^{\prime}$ & 1228 & 14.8 \\
\hline
\end{tabular}

HE, LE - High Elevation and Low Elevation P. tecunumanii respectively; " now classified as P. herrerae.

Table 2. - Details of climatic and Geographic factors of the four sites.

\begin{tabular}{|l|c|c|c|c|}
\hline \multirow{2}{*}{} & \multicolumn{4}{|c|}{ Sites } \\
\cline { 2 - 5 } & Stapleford & Gungunyana & Cashel & Maswera \\
\hline Altitude (m a.s.l.) & 1760 & 1050 & 1450 & 780 \\
\hline Latitude $\left({ }^{\circ} \mathrm{S}\right)$ & $18^{\circ} 41^{\prime}$ & $20^{\circ} 24^{\prime}$ & $19^{\circ} 25^{\prime}$ & $18^{\circ} 41^{\prime}$ \\
\hline Longitude $\left({ }^{\circ} \mathrm{E}\right)$ & $32^{\circ} 51^{\prime}$ & $32^{\circ} 43^{\prime}$ & $32^{\circ} 45^{\prime}$ & $32^{\circ} 55^{\prime}$ \\
\hline Mean annual rainfall $(\mathrm{mm})$ & 2159 & 1097 & 891 & 1498 \\
\hline Mean annual temperature $\left({ }^{\circ} \mathrm{C}\right)$ & 15.1 & 18.1 & 19.5 & 20.7 \\
\hline
\end{tabular}


such data can be transformed by square root transformation provided that the percentages range from 0 to $20 \%$ or 80 to $100 \%$ but not both. However, for a fixed effect model, a lack of normality is not critical provided the departure from normality is not of extreme (NETER et al., 1985, page 624; STEEL et al., 1997, page 174). The F-test for equality of treatment means is less affected by lack of normality, either in terms of the level of significance or power of the test (NETER et al., 1985; STEEL et al., 1997).

The analysis of variance was conducted on the data from all the 16 provenances to estimate the provenance least squares means for both forking and stem breakage, and also to test whether the differences in stem breakage and forking between the low and high elevation $P$. tecunumanii were statistically significant. The analysis of variance was performed using PROC GLM in the Statistical Analysis System (SAS, 1998). The appropriate statistical model used for analysis of variance of individual site data was a fixed effect model:

$$
Y_{i j k}=\mu+B_{i}+P_{j}+B P_{i j}+F(P)_{j k}+\varepsilon_{i j k}
$$

\section{Where,}

$Y_{i j k}$ is the observation in the $i j k^{\text {th }}$ family plot, $\mu$ is the site mean, $B_{i}$ is the fixed effect of the $i^{\text {th }}$ block, $P_{j}$ is the fixed effect of the $j \mathrm{t}^{\mathrm{h}}$ provenance, $B P_{i j}$ is the interaction effect between the $i^{\text {th }}$ block and $j^{\text {th }}$ provenance, $F(P)_{j k}$ is the fixed effect of the $k^{\text {th }}$ family of the $j^{\text {th }}$ provenance and $\varepsilon_{i j k}$ the experimental error, $E=\left[\varepsilon_{i j k}\right]=0$, $\operatorname{Var}\left[\varepsilon_{i j k}\right]=\sigma_{\varepsilon}^{2}$.
In order to compare the means of the high and low elevation $P$. tecunumanii, a single contrast was also done in the same model. The provenance least squares means of both the five- and eight year stem breakage and forking at individual sites were plotted as graphs.

A combined analysis of data from three sites that had significant levels of stem breakage and forking was done to test the presence of genotype*environment interaction (provenance* site and family*site interaction). The fixed effect model used for the data was:

$$
\begin{aligned}
Y_{i j k l}= & \mu+S_{i}+B(S)_{i j}+P_{k}+S P_{i k}+B P(S)_{i j k}+ \\
& F(P)_{k l}+S F(P)_{i k l}+\varepsilon_{i j k l}
\end{aligned}
$$

Where:

$Y_{i j k l}$ is the observation in the $i j k l^{\text {th }}$ plot, $\mu=$ the across site mean, $S_{i}$ the fixed effect of the $i^{\text {th }}$ site, $B(S)_{i j}$ the fixed effect of the $j^{\text {th }}$ block in the $i^{\text {th }}$ site, $P_{k}$ the fixed effect of the $k^{\text {th }}$ provenance, $S P_{i k}$ the interaction effect between the $i^{\text {th }}$ site and $k^{\text {th }}$ provenance, $B P(S)_{i j k}$ the interaction between the $j^{\text {th }}$ block of the $i^{\text {th }}$ site and the $k^{\text {th }}$ provenance, $F(P)_{k l}$ the effect of the $l^{\text {th }}$ family of the $k^{\text {th }}$ provenance, $S F(P)_{i k l}$ the interaction between $i^{\text {th }}$ site and the $l^{\text {th }}$ family and $\varepsilon_{i j k l}$ the experimental error, $E\left[\varepsilon_{i j k l}\right]=0, \operatorname{var}\left[\varepsilon_{i j k l}\right]=\sigma_{\varepsilon}^{2}$

\section{Results}

\section{Stem Breakage}

Provenance effects for both five- and eight-year mean percent stem breakage were significant at different

\begin{tabular}{|c|c|c|c|c|c|}
\hline \multirow[t]{2}{*}{ Source of Variation } & \multirow[t]{2}{*}{$\mathrm{DF}$} & \multicolumn{4}{|c|}{ Trail. } \\
\hline & & Brt5 & Brt8 & Frk5 & Frk8 \\
\hline \multicolumn{6}{|l|}{ (Stapleford) } \\
\hline Block & 4 & & & & \\
\hline Provenance & 15 & $5.00^{* * *}$ & $2.56^{* *}$ & $5.54^{\kappa * *}$ & $10.21^{* * * *}$ \\
\hline High vs Low $P$. tecunumanii & & $37.92^{* * * *}$ & $30.48^{* * * *}$ & $63.02^{* * *}$ & $131.9^{* * * *}$ \\
\hline Block x Provenance & & & & & \\
\hline Family(Provenance) & 144 & $1.16^{\mathrm{ns}}$ & $1.24^{*}$ & $1.23^{k}$ & $1.32^{*}$ \\
\hline Error & 649 & & & & \\
\hline \multicolumn{6}{|l|}{ (Gungunyana) } \\
\hline Block & 4 & & & & \\
\hline Provenance & 15 & $2.87^{* * *}$ & $4.63^{* * *}$ & $2.46^{* *}$ & $2.01^{*}$ \\
\hline High vs Low P. tecunumanii & & $25.64^{*+* *}$ & $36.48^{*+*}$ & $7.82^{+\alpha \star}$ & $0.69^{\mathrm{ns}}$ \\
\hline Block x Provenance & 60 & & & & \\
\hline Family(Provenance) & 144 & $1.51^{* * *}$ & $1.26^{*}$ & $0.97^{n s}$ & $1.43^{* *}$ \\
\hline Error & 640 & & & & \\
\hline \multicolumn{6}{|l|}{ (Cashel) } \\
\hline Block & 4 & & & & \\
\hline Provenance & 15 & $1.77^{*}$ & $2.27^{* *}$ & $2.27^{* *}$ & $3.07^{* * *}$ \\
\hline High vs Low $P$. tecunumanii & & $11.49^{* * * * *}$ & $4.58^{*}$ & $4.58^{*}$ & $20.30^{* * * *}$ \\
\hline Block x Provenance & 60 & & & & \\
\hline Family(Provenance) & 144 & $1.30^{* * *}$ & $0.90^{\mathrm{ns}}$ & $0.90^{\mathrm{ns}}$ & $1.25^{*}$ \\
\hline Error & 649 & & & & \\
\hline \multicolumn{6}{|l|}{ (Maswera) } \\
\hline Block & 4 & & & & \\
\hline Provenance & 15 & $0.87^{\mathrm{ns}}$ & $1.80^{*}$ & $2.24^{* *}$ & $2.07^{*}$ \\
\hline High vs Low $P$. tecunumanii & 1 & $0.01^{\mathrm{ns}}$ & $2.11^{\mathrm{ns}}$ & $2.21^{\mathrm{ns}}$ & $0.39^{\mathrm{ns}}$ \\
\hline Block x Provenance & 60 & & & & \\
\hline Family(Provenance) & 144 & $0.98^{\text {ns }}$ & $0.81^{\text {ns }}$ & $1.12^{\mathrm{ns}}$ & $1.08^{\mathrm{ns}}$ \\
\hline Error & 618 & & & & \\
\hline
\end{tabular}

Table 3. - ANOVA F-ratios for five and eight-year stem breakage (brt5 and brt8) and forking (fork5 and fork8) at individual sites.

ns for not significant at 5\%; *,* and ${ }^{* * *}$ for significant at $5 \%, 1 \%$ and $0.1 \%$ respectively. 

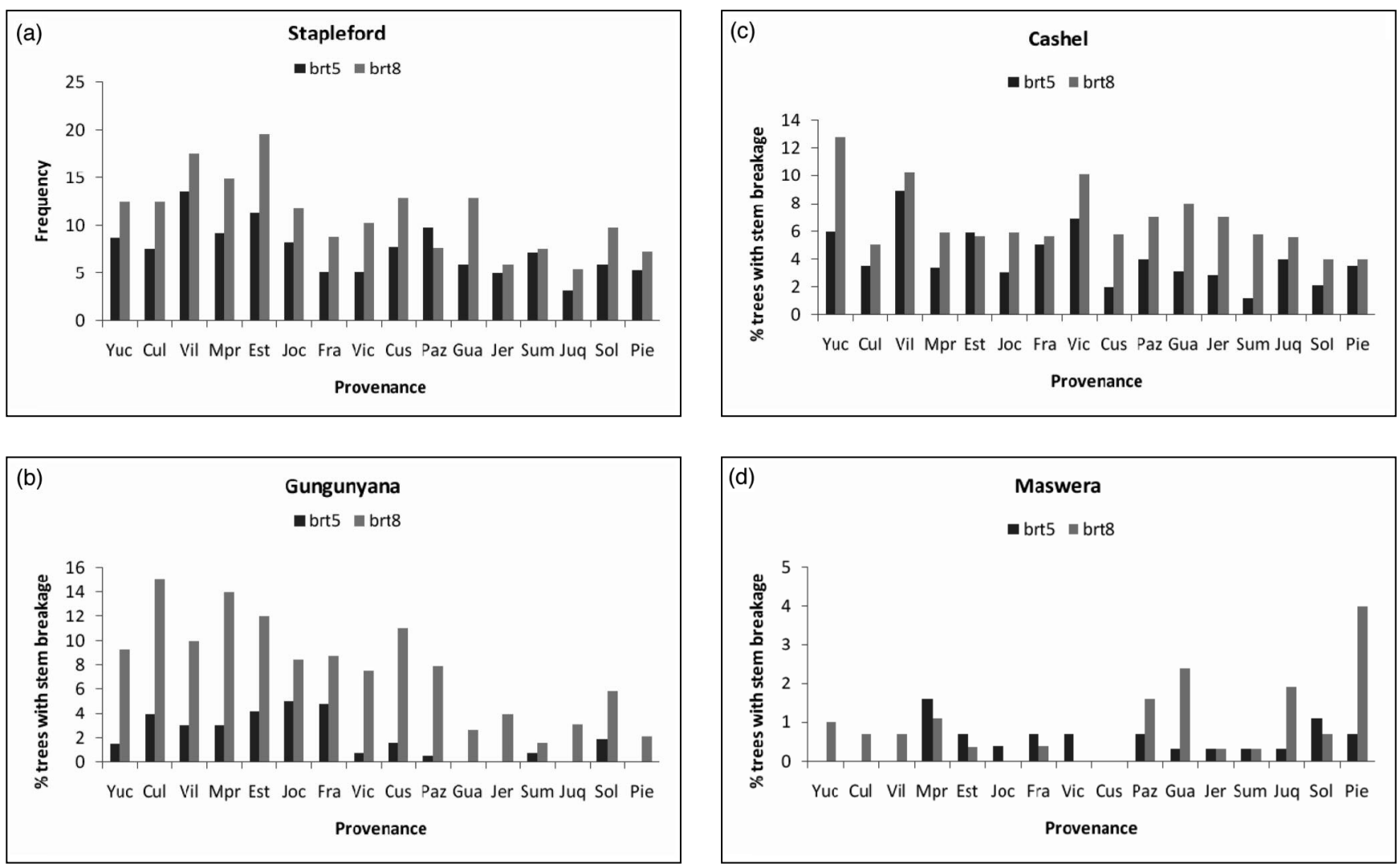

Figure 1. - Frequency of trees with stem breakage at (a) Stapleford, (b) Gungunyana, (c) Cashel and (d) Maswera at five and eight years. (Provenance codes are shown in Table 1).

probability levels at Stapleford, Gungunyana and Cashel but were only significant $(\mathrm{P}<0.05)$ for eight-year stem breakage at Maswera, the $4^{\text {th }}$ site (Table 3$)$. The contrast between the high and low elevation P. tecunumanii was significant at varying probability levels for both five- and eight-year stem breakage at Stapleford, Gungunyana and Cashel but was non-significant for both ages at Maswera. The family withinprovenance effect was significant at different probability levels at Gungunyana but was not significant at Maswera for both ages (Table 3). However, at Cashel and Stapleford, the family effect was only significant $(\mathrm{P}<0.05)$ for five- and eight-year stem breakage respectively.

The mean percent stem breakage of the 16 provenances at individual sites is shown in Figures 1. The mean stem breakage ranged from $3.2 \%$ to $19.5 \%$ at Stapleford; $0 \%$ to $15.1 \%$ at Gungunyana; $1.2 \%$ to 12.8 at Cashel and from $0 \%$ to $2.4 \%$ at Maswera. The mean percentage of trees with stem breakage at five and eight years averaged 7.4 and $11.6 \%$ at Stapleford, 4.1 and $6.8 \%$ at Cashel, 1.9 and $7.7 \%$ at Gungunyana and 0.5 and $1.0 \%$ at Maswera respectively. Across the four sites, the incidence of stem breakage was highest at Stapleford, the highest altitude test site and declined with decreasing altitude of the test site.

Overall, the provenances with the lowest levels of stem breakage at all the four sites included San Jerónimo, Montana Sumpul and Las Piedrecitas, all high elevation $P$. tecunumanii sources; Jocón, a low elevation
$P$. tecunumanii source and Juquila non-P. tecunumanii seed source. The number of trees with broken tops increased between five and eight years. The change was small to more than double on some of the sites.

\section{Forking}

The provenance effect for five and eight-year forking was significant at different probability levels at all the four sites (Table 3). The contrast between the low and high elevation $P$. tecunumanii was also significant at varying probability levels at Stapleford and Cashel for both the five- and eight-year forking. However, the same contrast was non-significant for both five-year and eight-year forking at Maswera and for eight-year forking at Gungunyana. The family within-provenance effect for forking which was significant $(\mathrm{P}<0.05)$ at Stapleford was non-significant at Maswera for both ages. At Gungunyana and Cashel, the same family within-provenance effect for forking was only significant at age eight years (Table 3 ).

Figure 2 shows the incidence of forking among the 16 provenances at the individual sites. The mean percent of forked trees ranged between $9.6 \%$ and $46.8 \%$ at Stapleford; $5.2 \%$ and $23.5 \%$ at Cashel; $1.8 \%$ and $23.5 \%$ at Gungunyana and $2.7 \%$ and $14.0 \%$ at Maswera. The percentage of forked trees at five and eight years averaged 18.1 and $31.2 \%$ at Stapleford, 9.7 and $15 \%$ at Cashel, 4.3 and $14.8 \%$ at Gungunyana and 5.4 and $8.0 \%$ at Maswera respectively. Overall, the incidence of forking was highest at Stapleford, the highest altitude test site 

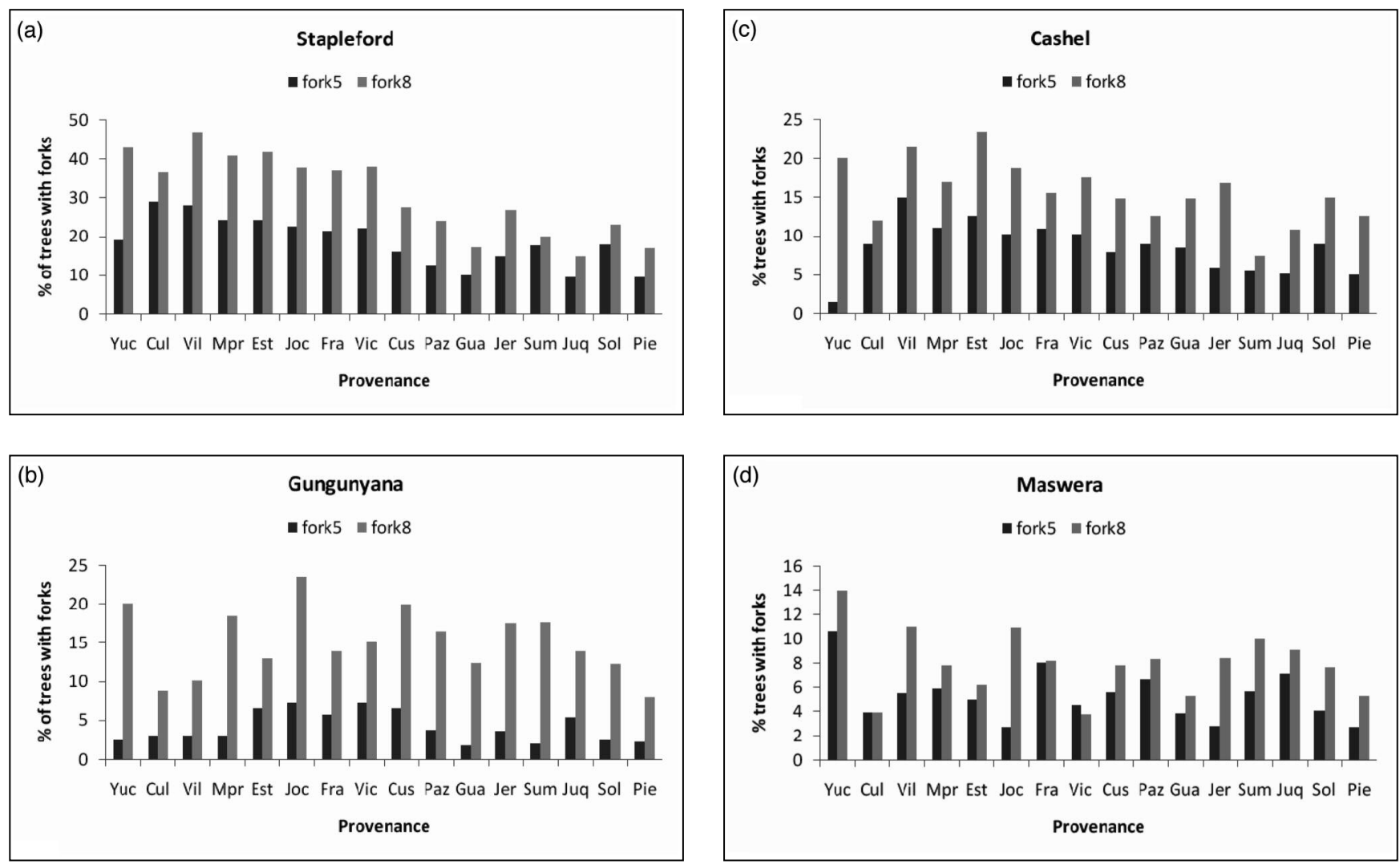

Figure 2. - Frequency of trees with forks at (a) Stapleford, (b) Gungunyana, (c) Cashel and (d) Maswera at five (fork5) and eight (fork8) years. (Provenance codes are shown Table 1).

and declined with decreasing altitude of the test site. The number of trees with forks increased between five and eight years. The change was small to more than double in some of provenances, depending on the site.

\section{Low versus High P. tecunumanii}

With the exception of Maswera site, where the differences were nonsignificant, the low elevation $P$. tecunumanii had significantly higher proportion of trees with stem breakage compared to the high elevation $P$. tecunumanii at the other three sites (Table 4). A similar pattern to that for stem breakage was also observed for forking in which, the low elevation $P$. tecunumanii had higher incidences of forked trees compared to the high elevation $P$. tecunumanii at again, three of four sites assessed (Table 4). The differences between the two $P$. tecunumanii types were less evident at Maswera.

\section{Genotype *Site Interaction}

The frequency of forking and stem breakage were very low at Maswera and consequently, data from this site was excluded in the across site analysis. Only data from the other three sites (Stapleford, Cashel and Gungunyana) that had significant levels of stem breakage and forking was used. Across the three sites, the site effect was highly significant at varying probability levels for all the traits, with the exception of eight-year stem breakage in the low elevation $P$. tecunumanii (Table 5). The provenance effects for all the four traits were however non significant in both the low and high elevation P. tecunumanii (Table 5). The family within-provenance

Table 4. - Percent means for five- and eight-year stem breakage (brt5 \& brt8) and forking (fork5 \& fork8) of the Low and High elevation $P$. tecunumanii at individual sites.

\begin{tabular}{|l|l|c|c|c|c|}
\hline \multirow{2}{*}{ Site } & Type of P. tecunumanii & \multicolumn{4}{|c|}{ Trait mean (\%) } \\
\cline { 3 - 6 } & & Brt5 & Brt8 & Fork5 & Fork8 \\
\hline Stapleford & Low Elevation & 9.1 & 13.9 & 23.6 & 40.8 \\
& High Elevation & 6.1 & 8.8 & 12.6 & 21.7 \\
\hline Cashel & Low Elevation & 5.4 & 7.7 & 12.4 & 18.7 \\
& High Elevation & 2.9 & 5.9 & 7.0 & 13.1 \\
\hline \multirow{2}{*}{ Gungunyana } & Low Elevation & 3.4 & 10.8 & 5.3 & $15.3 \mathrm{a}$ \\
& High Elevation & 0.6 & 4.8 & 3.4 & $14.1 \mathrm{a}$ \\
\hline Maswera & Low Elevation & $0.6 \mathrm{a}$ & $0.6 \mathrm{a}$ & $5.8 \mathrm{a}$ & $\mathbf{8 . 3 \mathbf { a }}$ \\
& High Elevation & $0.5 \mathrm{a}$ & $1.0 \mathrm{a}$ & $4.8 \mathrm{a}$ & $7.7 \mathrm{a}$ \\
\hline
\end{tabular}

Means within a box followed by a common letter do not differ significantly at $5 \%$ based on the contrasts. 
Table 5. - Analysis of Variance for five- and eight-year stem breakage (brt5 \& brt8) and forking (fork5 \& fork8) across three sites for both the Low and High elevation P. tecunumanii.

\begin{tabular}{|c|c|c|c|c|c|c|c|c|c|}
\hline \multirow[t]{2}{*}{ Source of variation } & \multirow[t]{2}{*}{$\mathrm{DF}$} & \multicolumn{4}{|c|}{ low elevation $P$. tecunumanii } & \multicolumn{4}{|c|}{ high elevation $P$, tecunumanii } \\
\hline & & Brt5 & Brt8 & Fork5 & Fork8 & Bit5 & Brt8 & Fork5 & Fork8 \\
\hline Site & 2 & $13.50^{\star \star *}$ & $1.98 \mathrm{~ns}$ & $52.08^{* * *}$ & $61.99^{\star \star *}$ & $22.67^{* * *}$ & $4.97^{*}$ & $24.30^{\star \star *}$ & $9.17^{* *}$ \\
\hline Block (Site) & 12 & & & & & & & & \\
\hline Provenance & 15 & $1.13 \mathrm{~ns}$ & $1.04 \mathrm{~ns}$ & $1.03 \mathrm{~ns}$ & $1.47 \mathrm{~ns}$ & $1.16 \mathrm{~ns}$ & $1.65 \mathrm{~ns}$ & $1.00 \mathrm{~ns}$ & $2.67 \mathrm{~ns}$ \\
\hline Site*Provenance & 30 & $1.73 \mathrm{~ns}$ & $1.33 \mathrm{~ns}$ & $1.14 \mathrm{~ns}$ & $1.00 \mathrm{~ns}$ & $1.00 \mathrm{~ns}$ & $2.09^{*}$ & $1.45 \mathrm{~ns}$ & $1.25 \mathrm{~ns}$ \\
\hline Block(Site) ${ }^{*}$ Provenance & 180 & & & & & & & & \\
\hline Family(Provenance) & 144 & $1.32 \mathrm{~ns}$ & $1.16 \mathrm{~ns}$ & $1.47^{*}$ & $1.52^{*}$ & $1.13 \mathrm{~ns}$ & $1.43^{*}$ & $1.45^{* *}$ & $1.29^{*}$ \\
\hline Site*Family(Provenance) & 288 & $1.03 \mathrm{~ns}$ & $1.09 \mathrm{~ns}$ & $1.06 \mathrm{~ns}$ & 1.09 & $1.29^{*}$ & $1.00 \mathrm{~ns}$ & $1.00 \mathrm{~ns}$ & $1.17^{*}$ \\
\hline Error & 1728 & & & & & & & & \\
\hline
\end{tabular}

ns for not significant at $5 \% ;{ }^{*},{ }^{* *}$ and ${ }^{* * *}$ for significant at $5 \%, 1 \%$ and $0.1 \%$ respectively

effect was only significant $(\mathrm{P}<0.05)$ for five- and eightyear forking in both the low and high elevation $P$. tecunumanii, while that for stem breakage was only significant at age eight years in the high elevation P. tecunumanii.

The site*provenance interaction effect, which was only significant for eight-year stem breakage in the high elevation $P$. tecunumanii, was mostly non-significant. The second interaction, the family* site interaction effect was only significant $(\mathrm{P}<0.05)$ for five-year stem breakage and eight-year forking in the high elevation $P$. tecunumanii. Overall, the two interactions were mostly non-significant and in few instances where they were significant, the level was always borderline and possibly of no consequence.

\section{Discussion and Conclusions}

The incidence of stem breakage and forking in both the low and high elevation $P$. tecunumanii was highest at the highest altitude test site (Stapleford) and declined with decreasing altitude. Stapleford is a relatively cool, wet and fertile site with a less pronounced dry season compared to Maswera, the lowest altitude test site, which although wetter, is relatively hotter, less fertile and has a very a long and pronounced dry season of up to 6 months. MourA and DvORAK (1998) reported a similar pattern in Brazil in which stem breakage was practically absent in the "Cerrado" region of Brazil. The "cerrado" is characterized by good rainfall but infertile soils and a distinct dry season. HoDGE and DvorAK (1999) also came to a similar conclusion based on an extensive study of international provenance trials in South Africa and a number of South American countries. In P. kesiya, Costa and LARS (2008) found significant provenance differences for forking in only four out of the seven trials measured; again implying that provenance differences in stem breakage and forking can be masked on some sites.

The results of the present study indicate that site selection, could be effective in managing stem breakage and forking in P. tecunumanii. Because the incidence of trees with stem breakage was higher on fertile sites with less pronounced dry season compared to less fertile sites that have distinct dry seasons, site selection could also be used as a tool to minimise the problem of forks and stem breakage. The ecological niche for $P$. tecunumanii in Zimbabwe as an exotic plantation species falls between areas that are currently being planted to sub-temperate species like $P$. patula and the subtropical species such as $P$. taeda and $P$. oocarpa (NYOKA et al., 2010).

Provenances of the low elevation $P$. tecunumanii are more prone to stem breakage compared to the provenances from the high elevation $P$. tecunumanii on medium to high altitude sites. The differences are however less apparent at lower altitudes. This finding is however, not consistent with that of HoDGE and DvORAK (1999), who reported greater incidences of stem breakage in high elevation $P$. tecunumanii compared to the low elevation $P$. tecunumanii in Colombia and South Africa. In their study, however, the two P. tecunumanii types were not evaluated in the same trials; therefore their comparison may probably have been less precise compared to the present one. Furthermore, only four high elevation $P$. tecunumanii provenances (Las Piedrecitas, San Jerónimo, La Soledad and Juquila) used in the present study, were also used in the study by HoDGE and DvoraK (1999). Although Juquila provenance was not very conspicuous among the $P$. tecunumanii provenances, the level of stem breakage and forking was always among the lowest.

In the study by DvorAK et al. (1993), the incidence of stem breakage was up to $44 \%$ on some sites compared to less than $20 \%$ in the present study. It is also worth noting that although the correlation between stem breakage and growth traits was not investigated in the present study, such correlations have been reported to be non-significant in other studies (DvorAK et al., 1993; PARFITT, 1996; Moura and DvorAK, 1998; HodGE and DVORAK, 1999).

The fact that the two traits had a similar pattern among the provenances and sites gave further credence to the suggestion by HODGE and DvORAK, (1999) to treat the two traits as one because the two traits could be different aspects of the same trait. The incidence of stem breakage and forking if combined into one trait, aver- 
aged over $25 \%$ at the worst affected site. This is a fairly high level that could deter planting of this species at some locations. In commercial forestry, trees with either broken tops or forked are usually targeted for silvicultural thinning in addition to other attributes such as trees with stunted growth, crooked stems and diseases. However a combination of site selection and seed source could be used as a management tool to minimise the impact of stem breakage and forking in P. tecunumanii plantations established from unimproved material. Based on stem breakage alone, as a selection criterion, provenances such as Montana Sumpul, Jocón, San Jerónimo and Las Piedrecitas for example, could be the right seed sources for planting at Stapleford where the incidence of stem breakage was less than six percent. In the study by HodGe and DvoraK (1999), the Jocón and Las Piedrecitas provenances were identified among the least susceptible to stem breakage, which is consistent with the present finding.

From this study, there is evidence that provenance and family variation in stem breakage and forking is present in both the low and high elevation $P$. tecunumanii. At individual sites, the variation appeared to be more pronounced at provenance level compared to family level. The genotype*environment interaction at provenance and family level for stem breakage and forking was less apparent in both types of $P$. tecunumanii. These results are in part consistent with other findings in the other species. In $P$. chiapensis, for example, DVORAK et al. (1996) reported significant provenance* site interactions for forking but the family*site interactions were non-significant. In a recent study of $P$. kesiya international provenance trials covering seven sites, CosTA and LARS (2008) also found the provenance*site interaction for forking to be less important.

Based on the results of this study, we concluded that the low elevation $P$. tecunumanii is more prone to stem breakage and forking compared to the high elevation $P$. tecunumanii. Stem breakage and forking appeared to be more pronounced on high altitude sites with prolonged growth period. On sites with a pronounced dry season, provenance and family differences are less apparent. Provenance and family variation in stem breakage and forking is present in both the low and high elevation P. tecunumanii. A combination of site and seed source selection could be used to minimise the negative impact of stem breakage and forking where unimproved material of $P$. tecunumanii is used in operational plantings.

\section{Acknowledgment}

The material used in this study was supplied by the Oxford Forestry institute, for which we are grateful. We are also grateful to the Station Managers of JOHN MeIKLe, Muguzo and Gungunyana Research Stations, Messrs T. MANGEzI, H. C. MHONGWEH and J. GARIGAYI for establishing, maintaining and assessing the trials. The late Dr. R. D. BARNES of the Oxford Forestry Institute, Oxford University gave guidance in the design and management of these trials.

\section{References}

Birks, J. S. and R. D. BARNES (1995): Provenance variation in Pinus caribaea, $P$. oocarpa and $P$. patula ssp. tecunumanii. Tropical Forestry Papers. 21: 40p.

CosTA, E. S. J and G. LARS (2008): Evaluation of an international series of Pinus kesiya provenance trials for growth and wood quality traits. Forest Ecology and Management 255: 3477-3488.

Crockford, K. J., A. J. Dunsdon, W. B. H. Baylis, J. S. BIRKS and R. D. BARNES (1990): Evaluation of tropical pine provenance and progeny tests. ODA Research Scheme R.4346. Oxford Forestry Institute, University of Oxford. Final Report. 136 pp.

DvoraK, W. S., C. E. BALOCCHI and R. H. RAYMOND (1989): Performance and stability of provenances and families of Pinus tecunumanii in the tropics and subtropics. In: Proc. Of an IUFRO conference on Breeding Tropical Trees: Population Structure and Genetic Improvement Strategies in Clonal and seedling forestry. Pattaya, Thailand, 28 November - 3 December, 1988, pp 187-196.

DvoraK, W. S., C. C. LAmbeth and B. Li (1993): Genetic and site effects on stem breakage in Pinus tecunumanii. New Forests 7: 237-253.

Dvorak, W. S., J. K. Donahue and J. A. Vasquez (1996): Provenance and progeny results for the tropical white pine, Pinus chiapensis, at five and eight years of age. New Forests 12: 125-140.

Dvorak, W. S., G. R. Hodge, E. A. Gutierrez, F. S. Malan and T. K. Stanger (2000a): Pinus tecunumanii. In: Conservation \& Testing of Tropical \& Subtropical Forest Tree Species by the CAMCORE Cooperative, College of Natural Resources, NSCU. Raleigh, NC. USA. pp. 188-209.

Dvorak, W. S., J. E. KietzKa, T. K. Stanger and M. MapULA (2000b): Pinus herrerae. In: Conservation \& Testing of Tropical \& Subtropical Forest Tree Species by the CAMCORE Cooperative, College of Natural Resources, NSCU. Raleigh, NC. USA. pp 75-84.

Dvorak, W. S., E. KietzKa, G. R. Hodge, A. Nel, G. A. dos SANTOS and C. GANTZ (2007): Assessing the potential of Pinus herrerae as a plantation species for the subtropics. Forest Ecology and Management Forest Ecology 242: 598-605.

EKLUNDH-EHRENBERG, C. (1963): Genetic variation in progeny tests of Scots pine (Pinus sylvestris L.). Studia Forestal Suecia 10: 1-135.

Hodge, G. R. and W. S. Dvorak (1999): Genetic Parameters and Provenance Variation in Pinus tecunumanii in 78 International Trials. Forest Genetics 6: 157-180.

Moura, V. P. G. and W. S. DvoraK (1998): Provenance and family performance of Pinus tecunumanii at 12 years of age in the Cerrado region of Brazil. Forest Genetics 5: 137-145.

Moura, P. G., W. S. DvoraK and G. R. Hodge (1998): Provenance and family variation of Pinus oocarpa grown in the Brazilian Cerrado References and further reading may be available for this article. To view references and further reading you must purchase this article.. Forest Ecology and Management 109: 315-322.

Moura, V. P. G. and W. S. DvoraK (2001): Provenance and family variation of Pinus caribaea var. hondurensis from Guatemala and Honduras, grown in Brazil, Colombia and Venezuela. Pesq. Agropec. Bras., Brasília 36: $225-234$. 
Neter, J. and W. WASSERMAN (1985): Applied Linear Statistical Models. Richard D. Irwin, Inc. Homewood, Illinois, 842 pp.

NYOKA, B. I. and R. D. BARNES (1995): Genetic parameters and provenance productivity of Pinus oocarpa and Pinus patula ssp. tecunumanii. South African Forestry Journal 173: 1-7.

Nyoka, B. I., P. Tongoona and C. M. Gumbie (in press): Provenance productivity of high and low elevation Pinus tecunumanii in Zimbabwe. Silvae Genetica 59(4): 189-199.

PARFITT, R. (1996): Stem breakage in Colombia and South Africa of Pinus tecunumanii from high elevation sources. Unpublished MSc thesis, University of Pretoria, South Africa. 67p.

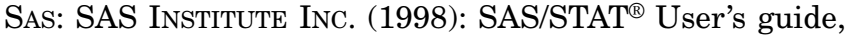
Release 6.03 Edition. Cary, NC, USA. 1028 pp.

StÅHL, E. G., B. Persson and E. Prescher (1990): Effect of provenance and spacing on stem straightness and number of stems with spike knots in Pinus sylvestris L. - Northern Sweden and countrywide models. Studia Forestal in Suecia 184: 1-16, ISBN 9157643458.

Steel, R. G. D., J. H. Torrie and D. A. Dickey (1997): Principles and Procedures of Statistics: a Biometrical Approach. $3^{\text {rd }}$ Edition, McGraw-Hill Inc., New York. 666pp.

\title{
Heritabilities, Intertrait Genetic Correlations, G x E Interaction and Predicted Genetic Gains for Acoustic Velocity in Mid-rotation Coastal Douglas fir
}

\author{
By K. J. S. JAYAwiCKRAMA ${ }^{1), 2)}$, T. Z. YE ${ }^{1)}$ and G. T. HowE ${ }^{1)}$
}

(Received 27 $7^{\text {th }}$ November 2009)

\begin{abstract}
Acoustic velocity (AV) data from 7,423 coastal Douglas-fir trees drawn from 347 wind-pollinated families on 14 sites, from four first-generation testing programs in the north Oregon Cascades, were analyzed. Families were measured on two or four sites at ages 23 to 41 years from seed using the Fakopp TreeSonic standingtree tool. Height (HT) and DBH data collected at ages 15 and 16 from seed, from all trees in the four programs (95,795 trees, 955 families), were used to calculate volume index $\left(\mathrm{VOL}=\mathrm{HT}^{*} \mathrm{DBH}^{2}\right)$ and stem taper $(\mathrm{TAP}=\mathrm{DBH} / \mathrm{HT})$. All traits were analyzed using multivariate mixed model analyses.

Across-site individual narrow-sense heritabilities for $\mathrm{AV}^{2}$ ranged from 0.24 to 0.40 among first-generation programs, compared to 0.12 to 0.23 for $\mathrm{HT}, 0.10$ to 0.16 for DBH, 0.11 to 0.20 for VOL and 0.14 to 0.17 for TAP.

Across-site type $\mathrm{B}$ correlations for $\mathrm{AV}^{2}$ ranged from 0.85 to 0.95 , compared to 0.62 to 0.83 for HT, 0.60 to 0.74 for DBH, 0.67 to 0.78 for VOL and 0.66 to 0.79 for TAP. $\mathrm{AV}^{2}$ was negatively correlated with $\mathrm{HT}$ in three programs $\left(\mathrm{r}_{\mathrm{A}}=0.17\right.$ to -0.28$)$, and negatively correlated with $\mathrm{DBH}(-0.12$ to -0.46$)$, VOL $(-0.05$ to -0.44$)$ and TAP $(-0.09$ to -0.40$)$ in all four programs.

Selecting the top $10 \%$ of the families sampled based on $\mathrm{AV}^{2}$ gave predicted gains of $4.4 \%$ to $9.6 \%$ for $\mathrm{AV}^{2}$ and

\footnotetext{
1) Department of Forest Ecosystems and Society, Oregon State University, Corvallis, OR 97331-5752, USA.

2) Corresponding Author: KeITH JAYAWICKRAMA. Tel: (541) 737 8432. Fax: (541)737 1393.

E-Mail: keith.jayawickrama@oregonstate.edu
}

$-9.3 \%$ to $10.6 \%$ for VOL. The adverse genetic correlations between $\mathrm{AV}^{2}$ and growth, and the losses in gain in $\mathrm{AV}^{2}$ from selection based on growth, may be overestimated by suppression of slower-growing families in these older tests.

Key words: acoustic velocity, dbh, Douglas-fir, genetic correlation, genetic gain, height, heritability, taper, volume index.

\section{Introduction}

Efficient selection and breeding of forest tree species to improve wood stiffness (modulus of elasticity, MOE) requires mass screening of progeny within large replicated field tests. Until recently ( 2000), the main limitation was the cost of measuring MOE on a large scale. Therefore, wood density was often used as a surrogate trait to improve wood stiffness (dynamic MOE = density $\mathrm{x}$ acoustic velocity ${ }^{2}$. Within the last 10 years, however, it has become possible to measure and use acoustic velocity $(\mathrm{AV})$ as a surrogate for MOE. This approach has been used in Douglas-fir and other conifers (JAYAWICKRAMA, 2001; KUMAR et al., 2002; CHERRY et al., 2008; MATHESON et al., 2008; JAYAWICKRAMA et al., 2009; WEILINGA et al., 2009), and is gaining acceptance as an approach to improve wood stiffness in operational breeding programs (JAYAWICKRAMA et al., 2009). In fact, compared to wood density, it may be preferable to measure and select solely on AV (e.g., Li et al., 2007) because it seems to have a higher correlation with static and dynamic MOE (JOHNSON and GARTNER, 2006; CHERRY et al., 2008). 